\title{
Simultaneous RNA quantification of human and retroviral genomes reveals intact interferon signaling in HTLV-1-infected CD4+ T cell lines
}

Britta Moens ${ }^{1}$, Christophe Pannecouque ${ }^{2}$, Giovanni López ${ }^{3}$, Michael Talledo ${ }^{3}$, Eduardo Gotuzzo ${ }^{3,4}$, Ricardo Khouri ${ }^{1,5}$, Achiléa Bittencourt ${ }^{6}$, Lourdes Farré ${ }^{5}$, Bernardo Galvão-Castro ${ }^{5,7}$, Anne-Mieke Vandamme ${ }^{1,8}$

and Johan Van Weyenbergh ${ }^{1,5,9^{*}}$

\begin{abstract}
Background: IFN-a contributes extensively to host immune response upon viral infection through antiviral, proapoptotic, antiproliferative and immunomodulatory activities. Although extensively documented in various types of human cancers and viral infections, controversy exists in the exact mechanism of action of IFN-a in human immunodeficiency virus type 1 (HIV-1) and human T-lymphotropic virus type 1 (HTLV-1) retroviral infections.

Results: IFN-a displayed strong anti-HIV-1 effects in HIV-1/HTLV-1 co-infected MT-4 cells in vitro, demonstrated by the dose-dependent inhibition of the HIV-1-induced cytopathic effect $\left(\mathrm{IC}_{50}=83.5 \mathrm{IU} / \mathrm{ml}, \mathrm{p}<0.0001\right)$ and p24 levels in cell-free supernatant $\left(I C_{50}=1.2 \mathrm{IU} / \mathrm{ml}, \mathrm{p}<0.0001\right)$. In contrast, IFN-a treatment did not affect cell viability or HTLV-1 viral mRNA levels in HTLV-1 mono-infected cell lines, based on flow cytometry and nCounter analysis, respectively. However, we were able to confirm the previously described post-transcriptional inhibition of HTLV-1 p19 secretion by IFN- $a$ in cell lines $(p=0.0045)$, and extend this finding to primary Adult T cell Leukemia patient samples $(p=0.031)$. In addition, through microarray and nCounter analysis, we performed the first genome-wide simultaneous quantification of complete human and retroviral transciptomes, demonstrating significant transcriptional activation of interferon-stimulated genes without concomitant decrease of HTLV-1 mRNA levels.

Conclusions: Taken together, our results indicate that both the absence of in vitro antiproliferative and pro-apoptotic activity as well as the modest post-transcriptional antiviral activity of IFN-a against HTLV-1, were not due to a cell-intrinsic defect in IFN-a signalisation, but rather represents a retrovirus-specific phenomenon, considering the strong HIV-1 inhibition in co-infected cells.
\end{abstract}

Keywords: Retrovirus, IFN-a, HIV-1, HTLV-1, IFN-a signaling, Antiviral activity

\section{Background}

The two pathogenic human retroviruses, human immunodeficiency virus type 1 (HIV-1) and human Tlymphotropic virus type 1 (HTLV-1), remain responsible for significant morbidity and mortality worldwide. At present, 33 million people are estimated to be infected with HIV-1 and 10 to 30 million people with HTLV-1 $[1,2]$. Although both retroviruses share similarities in

\footnotetext{
* Correspondence: johan@bahia.fiocruz.br

'Laboratory of Clinical and Epidemiological Virology, Rega Institute for Medical Research, K.U.Leuven, Leuven, Belgium

${ }^{5}$ Gonçalo Moniz Research Center, Oswaldo Cruz Foundation (FIOCRUZ), Salvador-Bahia, Brazil

Full list of author information is available at the end of the article
}

routes of transmission and in vivo tropism for $\mathrm{CD} 4+\mathrm{T}$ cells, HIV-1 and HTLV-1 significantly differ in pathogenicity, disease progression and treatment outcome. Current treatment of HIV-1-infected individuals is based on highly active antiretroviral therapy (HAART), combining HIV-1 reverse transcriptase, protease, integrase and/or entry inhibitors [3]. HAART reduces HIV-1 plasma viral loads to undetectable levels in the majority of patients, hereby slowing down clinical progression to the acquired immunodeficiency syndrome (AIDS). HTLV-1, on the other hand, is able to cause adult T cell leukemia/lymphoma (ATLL), as well as HTLV-1 associated myelopathy/tropical spastic paraparesis (HAM/ 
TSP), albeit in a minority of infected individuals $[1,4,5]$. ATLL is an aggressive $\mathrm{T}$ cell malignancy of mainly CD4 + CD25+ T cells, affecting up to 6\% of HTLV-1-infected individuals [5]. The diversity of patient symptoms together with their prognosis has led to the classification of ATLL into four clinical subtypes: acute, lymphoma, smouldering and chronic ATLL. Recently, consensus guidelines have been drafted for ATLL treatment with first line therapy comprising combination chemotherapy regimens for lymphoma patients and zidovudine (AZT) and interferon- $\alpha$ (IFN- $\alpha$ ) combination therapy for treatment of acute, smouldering and chronic ATLL patients $[6,7]$. Up to $5 \%$ of HTLV-1-infected individuals may develop HAM/TSP, a neuro-inflammatory disease characterized by demyelinating lesions and lymphocytic activation and infiltration into the central nervous system $[8,9]$. Treatment of HAM/TSP patients consists of mainly symptomatic (antispasmodics) and empirical strategies such as the use of immunosuppressive drugs (corticosteroids), IFN- $\alpha$ or vitamin C [10]. However, consensus guidelines for HAM/TSP treatment are missing due to the lack of randomized controlled clinical trials.

Although recent genetic evidence has implicated IFN/STAT1/FAS signaling in both HAM/TSP and ATL pathogenesis $[11,12]$, therapeutic options include IFN- $\alpha$ for both diseases. Initially, IFN- $\alpha$ was implemented in anti-HTLV-1 treatment because of its effect in HIV-1/ AIDS treatment [13]. IFN- $\alpha$ was one of the first cytokines to be discovered and contributes extensively to the host immune response upon viral infection. Type I interferons $(\mathrm{IFN}-\alpha / \beta)$ are expressed and secreted by various cell types in response to viral infection or recognition of pathogens [14-16]. IFN- $\alpha$ signaling pathways are initiated by binding of IFN- $\alpha$ to the heterodimeric interferon- $\alpha / \beta$ receptor, consecutively activating JAK/STAT pathways. Phosphorylated STAT1 homodimers and/or the interferon-stimulated gene factor 3 (ISGF3) complex, comprising phosphorylated STAT1, phosphorylated STAT2 and interferon regulatory factor 9 (IRF9), are formed, leading to the transcriptional activation of interferon-stimulated genes (ISGs) $[17,18]$. Classical well-characterized ISGs include 2,5'-oligoadenylate synthetase (OAS), protein kinase $\mathrm{R}$ (PKR), interferon regulatory factors (IRFs) and myxovirus resistance $(\mathrm{Mx})$ genes $[15,17,19]$. Although the precise function of several other ISGs remains poorly understood, expression of ISGs inhibits replication of various types of viruses [19-23]. In addition to antiviral activity, IFN- $\alpha$ has profound effects on apoptosis and immune response in several types of human cancer and viral infections [16,24-31].

HIV-1 replication can be inhibited in vitro by IFN- $\alpha$ in both macrophages as well as $\mathrm{T}$ cells, affecting both early and late stages of the viral replication cycle [20,32-38]. Antiviral activity of IFN- $\alpha$ was characterized by the expression of numerous ISGs. However, the in vivo antiviral activity of IFN- $\alpha$ and its contribution to HIV-1 disease progression remain controversial and need to be further elucidated. Higher levels of serum IFN- $\alpha$, IFN- $\alpha$-induced immune activation and higher transcriptional levels of ISGs are paradoxically correlated with higher HIV-1 viral load in HIV-1-infected individuals [39-43], as well as disease progression, questioning its antiviral activity in vivo. Nevertheless, clinical trials have reported modest but significant decreases in HIV-1 viral load after IFN- $\alpha$ treatment [13,44-46].

In HTLV-1-infected cells, in vitro antiviral activity has been reported for IFN- $\alpha$ by a post-transcriptional mechanism impairing viral assembly. Hereby, IFN- $\alpha$ had no effect on viral protein synthesis, but inhibited virion release through the inhibition of Gag protein association with lipid rafts [47]. In addition, IFN- $\alpha$ stimulation induced transcriptional activation of ISGs in HTLV-1infected cells, reflecting intact IFN- $\alpha$ signaling pathways [48]. However, HTLV-1 expression has been reported to blunt IFN- $\alpha$ signaling pathways in vitro via HTLV-1 Tax and suppressor of cytokine signaling 1 (SOCS1) expression [48-50]. Such inhibition could impair antiviral, immunomodulatory and antiproliferative activities of IFN- $\alpha$ in vivo. Nevertheless, significant clinical benefit has been demonstrated for ATLL patients treated with AZT and IFN- $\alpha$ combination therapy and HAM/TSP patients treated with IFN- $\alpha$ monotherapy [7,51,52]. In conclusion, although IFN- $\alpha$ signaling pathways contribute extensively to the host immune and antiviral responses and therefore significantly determine the therapeutic success of IFN- $\alpha$ treatment, controversy exists in the exact mechanism of action of IFN- $\alpha$ in retroviral infections.

In the present study, we address the possible antiviral, antiproliferative and/or pro-apoptotic effects of IFN- $\alpha$ in HTLV-1 mono-infected and HIV-1/HTLV-1 co-infected $\mathrm{CD} 4+\mathrm{T}$ cell lines in vitro. We demonstrate that IFN- $\alpha$ exerts pronounced anti-HIV-1 effects in HTLV-1 coinfected cells, but has a limited, post-transcriptional, antiviral effect upon HTLV-1 in mono-infected cells. As demonstrated by gene expression profiling, both STAT1/ STAT2-mediated antiviral signaling pathways and broad ISGs induction were fully activated by IFN- $\alpha$ in HTLV1 -infected cells. However, IFN- $\alpha$ failed to inhibit mRNA levels of any of the known HTLV-1 genes or to induce significant pro-apoptotic or antiproliferative activity in HTLV-1-infected cells. In conclusion, the apparent absence of IFN- $\alpha$ antiretroviral activity is selective towards HTLV-1, since a significant anti-HIV-1 effect can be observed in co-infected cells. 


\section{Results}

IFN- $a$ selectively affects cell viability of HIV-1/HTLV-1 coinfected but not HTLV-1 mono-infected cells

To assess the effects of IFN- $\alpha$ on cell viability of HTLV1 -infected cell lines, we quantified pro-apoptotic (activecaspase 3) and proliferation-associated (PCNA) markers via flow cytometry after IFN- $\alpha$ treatment $\left(10-10^{3} \mathrm{IU} / \mathrm{ml}\right)$ at different time points. As illustrated in Figure 1, IFN- $\alpha$ had no marked effect upon active-caspase 3-positive cells in three different HTLV-1-infected CD4+ T cell lines (C8166, MT-2 and MT-4) at 24, 48 and 72 hours of treatment. C8166 cells showed a spontaneous decline in proliferation (Figure 1A), reflected by pronounced time-dependent reduction in the percentage of PCNApositive cells, making them unsuitable for long-term experiments (> 72 hours), which were further on carried out only with MT-2 and MT-4 cells. We observed a modest, but significant, decrease in the percentage of PCNA-positive MT- 4 cells by $18.7 \pm 5.4 \%(n=6$, t-test, $\mathrm{p}=0.006$ ), after 48 hours of treatment (Figure $1 C-D$ ).
Quantification of additional cell death-associated markers (DNA fragmentation, surface Fas) revealed no proapoptotic activity of IFN- $\alpha$ in MT-4 cells after 48 hours of treatment (Figure 1D). Nevertheless, both MT-2 and MT-4 cells were resistant to IFN- $\alpha$ after 72 hours (Figure 1B-C) and even in long-term culture (15 days, data not shown), with similar cell viability in comparison to untreated cells.

Using an established MTT assay [53], we assessed the effects of IFN- $\alpha$ on cell viability of HIV-1 $\mathrm{III}_{\mathrm{B}} / \mathrm{HTLV}-1$ co-infected MT-4 cells and HTLV-1 mono-infected MT4 cells (HIV-1 negative, HTLV-1 positive). After 5 days of in vitro stimulation with varying concentrations of IFN- $\alpha\left(10-10^{4} \mathrm{IU} / \mathrm{ml}\right)$, inhibition of the HIV-1-induced cytopathic effect (CPE) on MT-4 cells was measured and inhibitory concentration $\left(\mathrm{IC}_{50}\right)$ was calculated. IFN- $\alpha$ strongly inhibited the HIV-1-induced CPE on the coinfected MT-4 cells with a mean $\mathrm{IC}_{50}$ of $\pm 83.5 \mathrm{IU} / \mathrm{ml}$ ( $\mathrm{n}=3$, area under curve, $\mathrm{p}<0.0001,2519 \pm 91.22$ versus $7316 \pm 115.2$, Figure $2 \mathrm{~A})$. In contrast, cell viability of
A

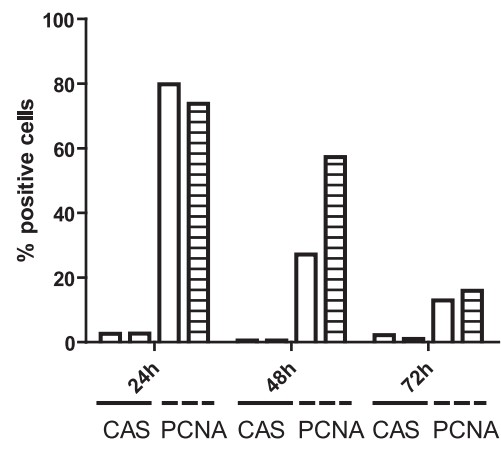

$\mathrm{C}$

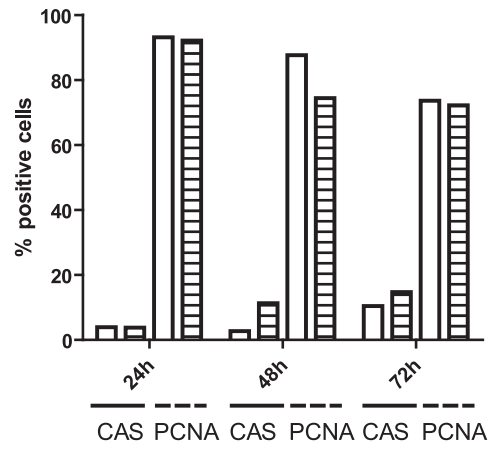

B

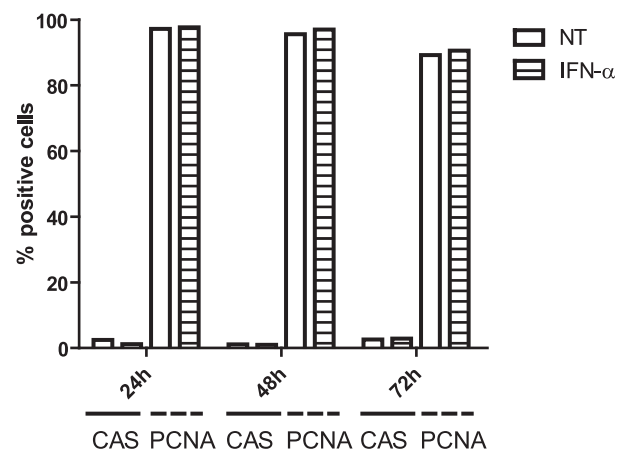

$\mathrm{D}$

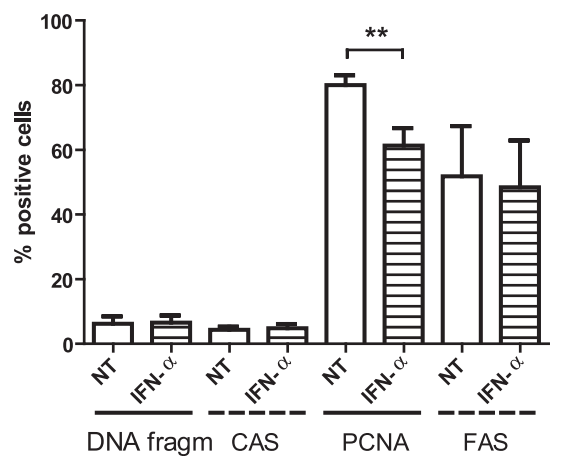

Figure 1 Flow cytometric analysis of cell death- and cell proliferation-associated markers of HTLV-1-infected cell lines. HTLV-1-infected CD4+ T cell lines, (A) C8166, (B) MT-2 and (C) MT-4 were treated for 24, 48 and 72 hours with no treatment (NT) or IFN-a, illustrated here for a fixed concentration of $1000 \mathrm{IJ} / \mathrm{ml}$. The percentage of active-caspase 3-positive cells (CAS) and proliferating cell nuclear antigen-positive cells (PCNA) were determined by flow cytometry and shown in the $y$-axis. The time points of treatment together with the treatment conditions are shown in the $x$-axis. (D) MT-4 cells were treated for 48 hours with no treatment (NT) or IFN-a (1000 IU/ml) in six independent experiments. Flow cytometric quantification of cells with DNA fragmentation (Hoechst 33342-positive cells), active-caspase 3-positive cells (CAS), proliferating cell nuclear antigen-positive cells (PCNA) and Fas receptor-positive cells (FAS) are shown in the $y$-axis, whereas the treatment conditions are shown in the $x$-axis. Parametric t-tests were used with p-values indicated by asterisks $\left({ }^{*}<0.05,{ }^{* *}<0.01\right.$ and $\left.^{* * *}<0.001\right)$. 


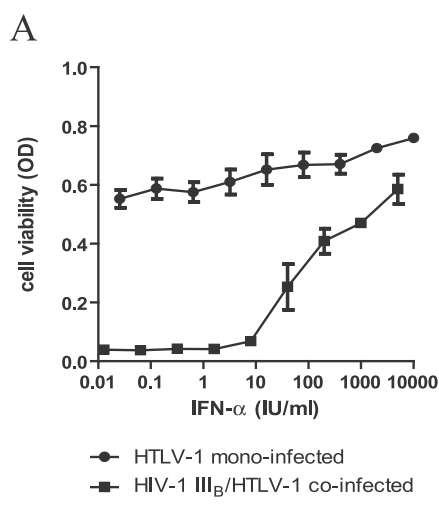

$\mathrm{C}$

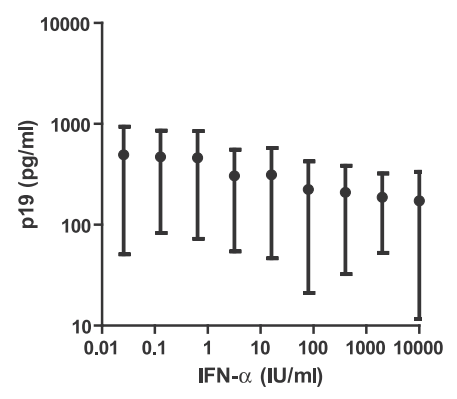

$\mathrm{E}$

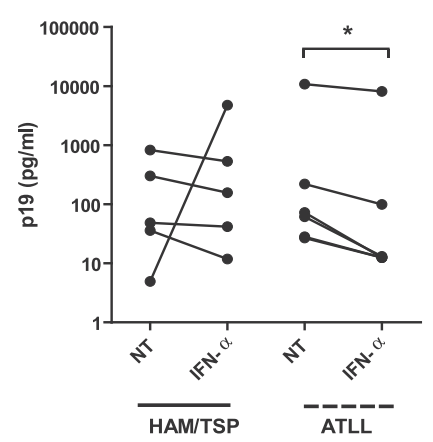

B

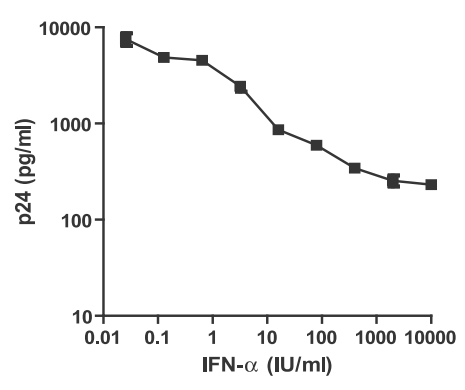

$\mathrm{D}$

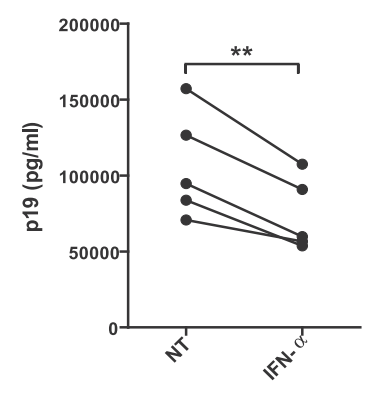

Figure 2 Cell viability, HIV-1 p24 and HTLV-1 p19 levels of HTLV-1 co- and mono-infected cells. HIV-1 III $\mathrm{B}_{\mathrm{H}} \mathrm{HTLV}-1$ co-infected and HTLV-1 mono-infected MT-4 cells were cultured in the absence or presence of varying concentrations of IFN-a $\left(0-10^{4} \mathrm{IU} / \mathrm{ml}\right)$. (A) Cell viability was determined after 5 days of culture, based on reduction of MTT and expressed in optical density (OD). In parallel, (B) HIV-1 p24 protein and (C) HTLV-1 p19 protein concentrations $(\mathrm{pg} / \mathrm{ml})$, were determined in cell-free supernatant of HIV-1/HTLV-1 co-infected and HTLV-1 mono-infected MT-4 cells, respectively, after 48 hours of culture. In addition, (D) HTLV-1 positive MT-2 cells were treated for 48 hours with no treatment (NT) or a fixed concentration of $1000 \mathrm{IU} / \mathrm{ml}$ of IFN-a, followed by quantification of HTLV-1 p19 protein levels in cell-free supernatant. (E) HTLV-1 p19 protein levels were also determined in cell-free supernatant of PBMCs of HAM/TSP $(n=5)$ and ATLL $(n=6)$ patients, after 48-72 hours of culture in the absence or presence of IFN-a $(1000 \mathrm{IU} / \mathrm{ml})$. Parametric t-tests were used with $\mathrm{p}$-values indicated by asterisks $\left({ }^{*}<0.05,{ }^{* *}<0.01\right.$ and $\left.{ }^{* * *}<0.001\right)$.

HTLV-1 mono-infected MT-4 cells was not affected by IFN- $\alpha$ treatment as demonstrated by a mean cytotoxic concentration $\left(\mathrm{CC}_{50}\right)$ higher than $10^{4} \mathrm{IU} / \mathrm{ml}$ (highest concentration tested, $n=3$, Figure $2 A$ ), supporting flow cytometric observations in MT-4 cells.

IFN- $a$ induces a 1000-fold greater reduction of HIV-1 p24 vs. HTLV-1 p19 protein levels

Although IFN- $\alpha$ strongly induced anti-HIV-1 activity in MT-4 cells, we observed no "anti-HTLV-1" activity of
IFN- $\alpha$ in MT- 4 cells based on cell viability data (MTT reduction and flow cytometry). Since HIV-1 p24 and HTLV-1 p19 levels are bona fide readouts of virion production, we quantified these viral proteins in cell-free supernatant of $\mathrm{HIV}-1 \quad \mathrm{III}_{\mathrm{B}} / \mathrm{HTLV}-1$ co-infected and HTLV-1 mono-infected MT-4 cells, respectively, treated with increasing concentrations of IFN- $\alpha$ for 48 hours $(\mathrm{n}=3)$. IFN- $\alpha$ dose-dependently reduced HIV-1 p24 levels (ANOVA, $\mathrm{p}<0.0001$, Bonferroni post-test, $\mathrm{p}<0.05$, significant from $0.64 \mathrm{IU} / \mathrm{ml}$ ), with a mean $\mathrm{IC}_{50}$ of $1.2 \mathrm{IU} / \mathrm{ml}$ 
and thus reflecting strong inhibition of HIV-1 p24 production and/or secretion in HIV-1/HTLV-1 co-infected MT-4 cells (Figure 2B). In parallel, IFN- $\alpha$ did not markedly affect HTLV-1 p19 levels in cell-free supernatant of HTLV-1 mono-infected MT-4 cells (ANOVA, $\mathrm{p}=0.96$ ), even at high doses (Figure 2C). In addition, HTLV-1 p19 protein levels were also determined in cell-free supernatant of the HTLV-1 positive and virion-producing MT2 cell line. To obtain maximum biological activity, MT-2 cells were treated for 48 hours with a fixed concentration of $1000 \mathrm{IU} / \mathrm{ml}$ of IFN- $\alpha$. IFN- $\alpha$ significantly reduced p19 levels in cell-free supernatant of MT-2 cells by $31 \%(n=5$, $\mathrm{t}$-test, $\mathrm{p}=0.0045$, Figure 2D), confirming the results of Feng et al. [47]. Nevertheless, IFN- $\alpha$ was 1,000 -fold more active against HIV-1 than HTLV-1, when judged according to the inhibition of Gag protein levels (p24 for HIV-1 and p19 for HTLV-1). In HIV-1 $\mathrm{III}_{\mathrm{B}} / \mathrm{HTLV}-1$ co-infected MT4 cells, $1.2 \mathrm{IU} / \mathrm{ml}$ of IFN- $\alpha$ inhibited $50 \%$ of HIV-1 p24 levels, whereas $1000 \mathrm{IU} / \mathrm{ml}$ of IFN- $\alpha$ was not even sufficient to inhibit $50 \%$ of HTLV-1 p19 levels in HTLV-1 mono-infected cells.

To evaluate the potential clinical relevance of this observation, we quantified HTLV-1 p19 levels in cell-free supernatant of HAM/TSP $(n=5)$ and ATLL $(n=6)$ PBMCs. IFN- $\alpha$ exerted no significant effect upon p19 levels of HAM/TSP PBMCs $(t$-test, $\mathrm{p}=0.63)$, in agreement to our recent demonstration of a lack of ex vivo antiviral, pro-apoptotic and antiproliferative effects of IFN- $\alpha$ in HAM/TSP patients [54]. However, IFN- $\alpha$ significantly decreased p19 levels of ATLL PBMCs with $26 \%(t$-test, $\mathrm{p}=0.031$ ) (Figure $2 \mathrm{E}$ ). This modest reduction of p19 levels observed in ATLL PBMCs was highly similar to the IFN- $\alpha$-induced reduction observed in MT-2 cells (Figure 2D) and to recent findings in larger cohorts of HTLV-1-infected individuals [55] as well as ATL patients (Khouri et al., unpublished).

\section{Gene expression profiling of IFN-a-treated HTLV-1- infected cell lines}

While HIV-1 replication was extremely sensitive to IFN$\alpha$ antiviral activity in HIV-1/HTLV-1 co-infected MT-4 cells, anti-HTLV-1 activity remains questionable since we did not detect an effect of IFN- $\alpha$ on cell viability of HTLV-1 mono-infected cells. However, we could measure a modest inhibitory effect of IFN- $\alpha$ on HTLV-1 p19 protein levels in MT-2 cells. To clarify whether IFN- $\alpha$ signaling is blunted in HTLV-1-infected cell lines, possibly explaining the lack of IFN- $\alpha$ responsiveness, we performed gene expression profiling of MT-2 and MT-4 cells after 6 hours of IFN- $\alpha$ stimulation. Agilent Whole Humane Genome microarray analysis was performed in two separate microarray experiments with duplicate samples for both cell lines. Gene expression profiling of MT-2 revealed 77 genes significantly regulated by IFN- $\alpha$, of which 64 were up- and 13 down-regulated. Gene expression profiling of MT-4 revealed 284 genes significantly regulated by IFN- $\alpha$, of which 262 were up- and 22 down-regulated. The top 20 of the most significant upregulated genes are shown in Table 1 for MT-2 and Table 2 for MT-4 cells, and included classical ISGs such as Mx, OAS and IRFs genes. We found no common down-regulated genes for MT-2 and MT-4, while 69\% (44/64) of up-regulated genes of MT-2 were also upregulated in MT-4 cells. Altogether, gene expression profiling demonstrated significant activation of ISGs and thus intact IFN- $\alpha$ signaling in HTLV-1-infected MT-2 and MT-4 cells.

\section{Pathway analysis confirms intact IFN- $a$ antiviral signaling pathways in HTLV-1-infected cell lines}

In order to characterize possible antiviral, pro-apoptotic and/or antiproliferative pathways represented by the respective IFN- $\alpha$ up- and down-regulated genes, which were identified via microarray analysis described above, Ingenuity Pathway Analysis (IPA) was performed for both cell lines. Genes were sorted into molecular gene networks and canonical pathways, of which significantly overrepresented networks/pathways were identified. In the case of MT-2, seven molecular networks were identified as significantly modulated by IFN- $\alpha$ treatment. The principal network contained 25 genes, all up-regulated, representing antimicrobial and inflammatory responses. In the case of MT-4, 12 molecular networks could be identified as significantly modulated by IFN- $\alpha$ treatment. The principal network contained 26 genes, all up-regulated, representing infection mechanism. The principal IFN- $\alpha$-modulated canonical pathway was identical for both cell lines, i.e. interferon signaling (Figure 3), although subtle differences were observed (IFN- $\gamma$, MX1, up-regulated only in MT-2 and JAK2, SOCS1, IRF1, TAP1, OAS1, up-regulated only in MT-4). Thus, IPA illustrated IFN- $\alpha$-induced modulation of molecular networks and pathways implicated in viral infection and/or IFN signaling in both cell lines. Moreover, no apoptotic, cell cycle-related or antiproliferative pathways were identified, corroborating our flow cytometry findings that IFN- $\alpha$ had no effect on cell viability of HTLV-1infected cell lines.

\section{Lack of antiviral activity of IFN- $a$ in HTLV-infected cell lines}

To assess the possible antiviral activity of IFN- $\alpha$ against HTLV-1 and to validate cellular genes identified through microarray analysis, nCounter analysis was performed [56]. All known HTLV-1 viral genes, including the antisense HBZ, and a selection of specific cellular genes, i.e. STAT1, STAT2, STAT3 and CD69, an IFN-induced early activation marker of $\mathrm{T}$ lymphocytes, were included for 
Table 1 Overview of the $\mathbf{2 0}$ most significant up-regulated genes by IFN- $a$ treatment in MT- 2 cells

\begin{tabular}{|c|c|c|}
\hline $\begin{array}{l}\text { Gene } \\
\text { Symbol }\end{array}$ & GAN & Gene Name \\
\hline $\mathrm{MX1}$ & NM_002462 & $\begin{array}{l}\text { myxovirus (influenza virus) resistance } 1 \\
\text { (mouse) }\end{array}$ \\
\hline DTX3L & NM_138287 & deltex 3-like (Drosophila) \\
\hline IFIT5 & NM_012420 & $\begin{array}{l}\text { interferon-induced protein with } \\
\text { tetratricopeptide repeats } 5\end{array}$ \\
\hline TMEM140 & NM_018295 & transmembrane protein 140 \\
\hline BCL2L14 & NM_030766 & BCL2-like 14 (apoptosis facilitator) \\
\hline EIF2AK2 & NM_002759 & $\begin{array}{l}\text { eukaryotic translation initiation factor } \\
\text { 2-alpha kinase } 2\end{array}$ \\
\hline SP100 & NM_001080391 & SP100 nuclear antigen \\
\hline EPSTI1 & AL831953 & epithelial stromal interaction 1 (breast) \\
\hline RTP4 & NM_022147 & $\begin{array}{l}\text { receptor (chemosensory) transporter } \\
\text { protein } 4\end{array}$ \\
\hline RSAD2 & NM_080657 & $\begin{array}{l}\text { radical S-adenosyl methionine domain } \\
\text { containing } 2\end{array}$ \\
\hline IRF7 & NM_004031 & interferon regulatory factor 7 \\
\hline TRIM21 & NM_003141 & tripartite motif-containing 21 \\
\hline $\mathrm{IFIH1}$ & NM_022168 & $\begin{array}{l}\text { interferon induced with helicase } C \\
\text { domain } 1\end{array}$ \\
\hline TRIM25 & NM_005082 & tripartite motif-containing 25 \\
\hline C19orf66 & NM_018381 & chromosome 19 open reading frame 66 \\
\hline PARP9 & NM_031458 & $\begin{array}{l}\text { poly (ADP-ribose) polymerase family, } \\
\text { member } 9\end{array}$ \\
\hline PML & NM_033244 & promyelocytic leukemia \\
\hline OAS3 & NM_006187 & 2'-5'-oligoadenylate synthetase 3, $100 \mathrm{kDa}$ \\
\hline |F|44 & NM_006417 & interferon-induced protein 44 \\
\hline XAF1 & NM_017523 & XIAP associated factor 1 \\
\hline
\end{tabular}

GAN: Genbank Accession Number.

nCounter analysis. mRNA levels of selected genes were quantified and normalized to a cellular housekeeping gene (hypoxanthine phosphoribosyl-transferase 1). IFN- $\alpha$ significantly increased mRNA levels of STAT1 and STAT2 genes in MT-2 and MT-4 cells $(n=4, t$-test, $\mathrm{p}=0.0024, \mathrm{p}=0.010$ and $\mathrm{p}=0.0023, \mathrm{p}=0.032$, respectively, Figure 4), confirming functional activation of JAK/STAT pathways and IFN- $\alpha$ antiviral signaling. Moreover, mRNA levels of cellular STAT3 and CD69 genes were also significantly increased in MT- 4 cells, confirming our microarray results $(\mathrm{n}=4, \mathrm{t}$-test, $\mathrm{p}=0.0041, \mathrm{p}=0.0018$, respectively, data not shown). As indicated by pathway analysis (Figure $5 \mathrm{~A}-\mathrm{B}$ ), IFN- $\alpha$ predominantly activated STAT1 and STAT2 signaling and downstream genes, representing main antiviral pathways, rather than STAT3 signaling, representing inflammatory and carcinogenic pathways. HTLV-1 viral mRNA levels were \pm 10-fold higher in MT-2 cells, in comparison to MT-4 cells, in agreement with the superior virion production by MT-2 cells (Figure 2C-D). Surprisingly, after 6 hours, IFN- $\alpha$ treatment had no effect on mRNA levels of any of the HTLV-1 viral genes in both cell lines $(\mathrm{n}=4, t$-test, Figure 6A-B). Due to the surprising absence of an antiviral effect at 6 hours, we also performed nCounter analysis after 2 and 48 hours of IFN- $\alpha$ treatment of MT-2 and MT-4 cells to verify whether "early" or "late" inhibition of HTLV-1 viral gene transcription might occur. At 2 hours, IFN- $\alpha$ again had no effect on viral gene mRNA levels in both cell lines $(\mathrm{n}=4, t$-test, data not shown). However, IFN- $\alpha$ significantly increased mRNA levels of STAT1 and STAT2 genes in MT-4 cells after 2 hours $(\mathrm{n}=4, t$-test, $\mathrm{p}=0.023$ and $\mathrm{p}=0.029$, respectively, Additional file 1), illustrating early activation of JAK/STAT pathways and IFN- $\alpha$ signaling. At 48 hours, IFN- $\alpha$ again failed to considerably down-regulate HTLV-1 viral gene transcription (Additional file 1) although IFN- $\alpha$ signaling was sustained in both MT-2 and MT-4 cells, demonstrated by increased STAT1 and STAT2 mRNA

Table 2 Overview of the $\mathbf{2 0}$ most significant up-regulated genes by IFN- $a$ treatment in MT-4 cells

\begin{tabular}{|c|c|c|}
\hline $\begin{array}{l}\text { Gene } \\
\text { Symbol }\end{array}$ & GAN & Gene Name \\
\hline IFIT1 & NM_001548 & $\begin{array}{l}\text { interferon-induced protein with } \\
\text { tetratricopeptide repeats } 1\end{array}$ \\
\hline STAT1 & NM_007315 & $\begin{array}{l}\text { signal transducer and activator of } \\
\text { transcription } 1,91 \mathrm{kDa}\end{array}$ \\
\hline ADAR & NM_001111 & adenosine deaminase, RNA-specific \\
\hline IFIT5 & NM_012420 & $\begin{array}{l}\text { interferon-induced protein with } \\
\text { tetratricopeptide repeats } 5\end{array}$ \\
\hline IRF1 & NM_002198 & interferon regulatory factor 1 \\
\hline APOL6 & NM_030641 & apolipoprotein L, 6 \\
\hline MX2 & NM_002463 & $\begin{array}{l}\text { myxovirus (influenza virus) resistance } 2 \\
\text { (mouse) }\end{array}$ \\
\hline HAPLN3 & NM_178232 & hyaluronan and proteoglycan link protein 3 \\
\hline EIF2AK2 & NM_002759 & $\begin{array}{l}\text { eukaryotic translation initiation factor } \\
\text { 2-alpha kinase } 2\end{array}$ \\
\hline BCL2L14 & NM_030766 & BCL2-like 14 (apoptosis facilitator) \\
\hline LAP3 & NM_015907 & leucine aminopeptidase 3 \\
\hline IRF7 & NM_004029 & interferon regulatory factor 7 \\
\hline ZBTB32 & NM_014383 & zinc finger and BTB domain containing 32 \\
\hline SP100 & NM_001080391 & SP100 nuclear antigen \\
\hline EPSTI1 & NM_033255 & epithelial stromal interaction 1 (breast) \\
\hline TBX21 & NM_013351 & T-box 21 \\
\hline SAMD9L & NM_152703 & sterile alpha motif domain containing 9-like \\
\hline$|F| 27$ & NM_005532 & interferon, alpha-inducible protein 27 \\
\hline TAP1 & NM_000593 & $\begin{array}{l}\text { transporter 1, ATP-binding cassette, sub- } \\
\text { family B (MDR/TAP) }\end{array}$ \\
\hline TNFSF13B & NM_006573 & $\begin{array}{l}\text { tumor necrosis factor (ligand) superfamily, } \\
\text { member } 13 \mathrm{~b}\end{array}$ \\
\hline
\end{tabular}

GAN: Genbank Accession Number. 


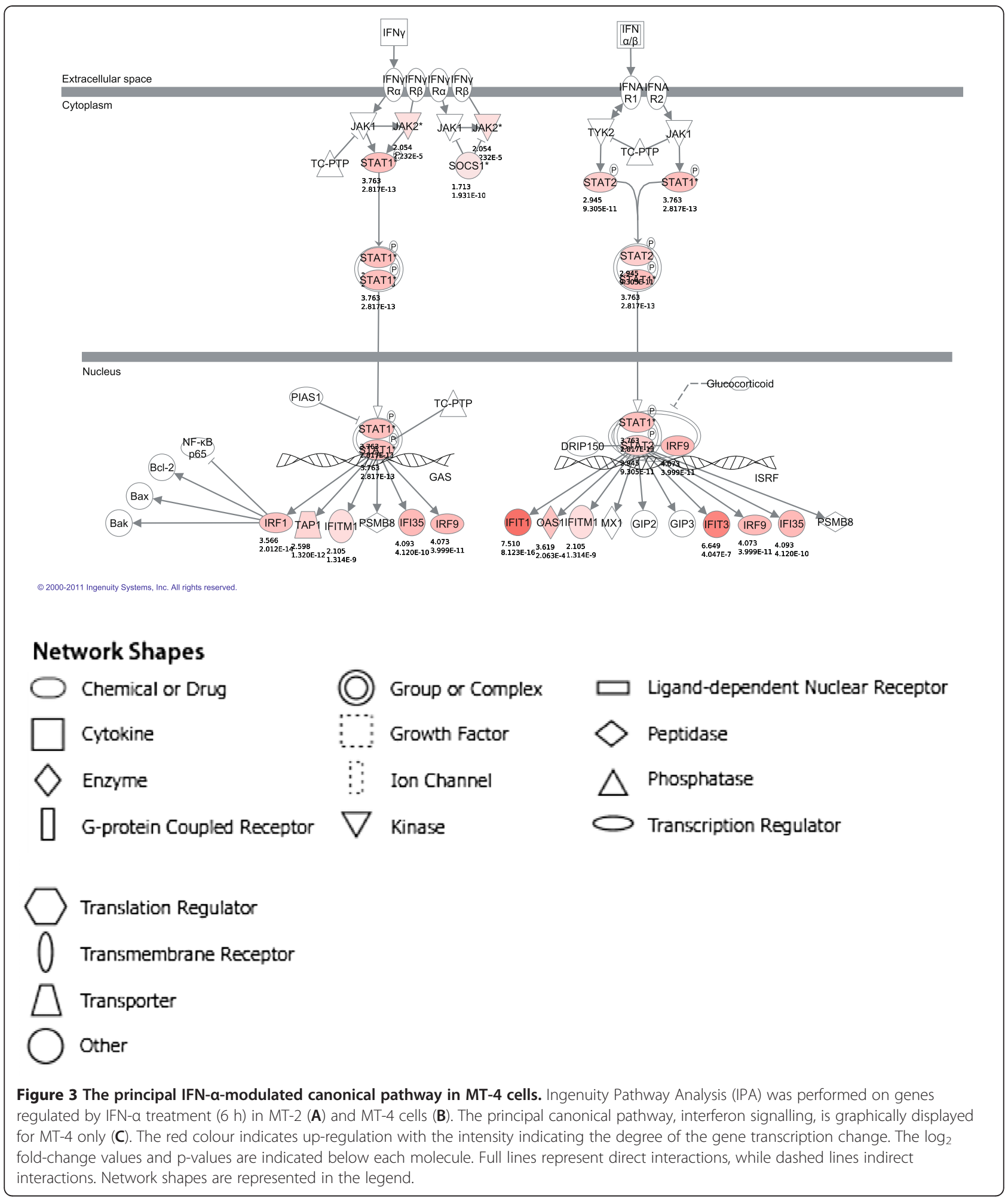

levels (Additional file 1). Altogether, IFN- $\alpha$ treatment induced intact and sustained IFN- $\alpha$ signaling in HTLV-1infected cell lines, without any antiviral activity at the transcriptional level, as all HTLV-1 viral mRNA levels were unaffected after 2, 6 and 48 hours of IFN- $\alpha$ treatment.

\section{Discussion}

IFN- $\alpha$ treatment exerted a strong in vitro anti-HIV-1 effect in HIV-1/HTLV-1 co-infected MT-4 cells, demonstrated by the dose-dependent inhibition of the HIV-1induced CPE and p24 secreted levels upon HIV-1 


\section{A}

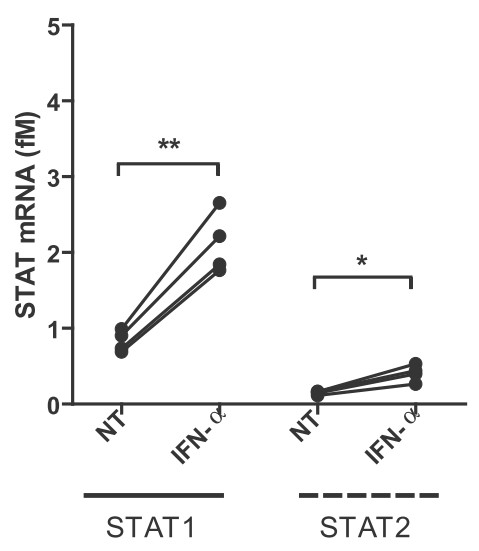

B

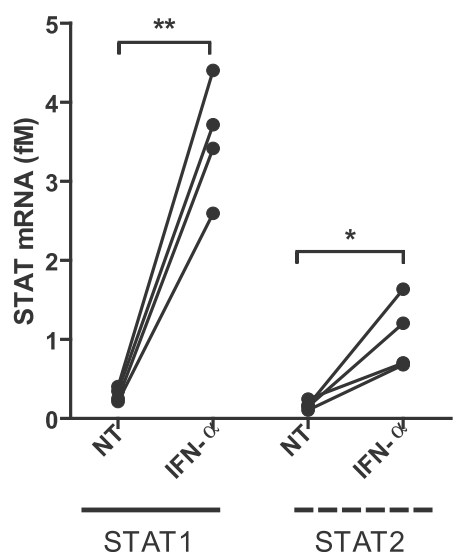

Figure 4 Quantification of STAT1 and STAT2 mRNA levels of HTLV-1-infected cell lines. HTLV-1-infected CD4+ T cell lines (A) MT-2 and (B) MT-4 were treated for 6 hours with no treatment (NT) or IFN-a (1000 IU/ml). mRNA levels (fM) of cellular STAT1 and STAT2 genes were assessed via nCounter analysis and shown in the $y$-axis, whereas the treatment conditions are shown in the $x$-axis. Parametric t-tests were used with p-values indicated by asterisks $\left({ }^{*}<0.05,{ }^{* *}<0.01\right.$ and $\left.{ }^{* * *}<0.001\right)$.

infection. In contrast, IFN- $\alpha$ treatment did not affect cell viability of HTLV-1-infected cell lines C8166, MT-2 nor MT-4. Furthermore, we demonstrate for the first time that IFN- $\alpha$ treatment did not affect HTLV-1 viral mRNA levels in MT-2 and MT-4 cells, demonstrated by nCounter analysis at various time points. Although these observations suggest the lack of biological activity of IFN- $\alpha$ against HTLV-1, we were able to confirm the previously described post-transcriptional inhibition of HTLV-1 p19 secretion by IFN- $\alpha$ [47], both in cell lines as well as in ATL patient samples. However, in comparison to the strong dose-dependent inhibition of HIV-1 p24 levels, IFN- $\alpha$ only modestly reduced p19 levels in cell-free supernatant of MT-2 cells and ATL PBMCs. Despite the absence of pronounced antiviral, pro-apoptotic and antiproliferative activity of IFN- $\alpha$, microarray and nCounter analysis revealed significant transcriptional activation of ISGs and intact IFN- $\alpha$ signaling in MT-2 and MT-4 cells. MT-4 cells appeared to be more responsive to IFN- $\alpha$ treatment in comparison to MT-2 cells, demonstrated by significant up- or down-regulation of 284 vs. 77 genes, respectively, and the early activation of STAT1 and STAT2 genes. Nevertheless, approximately 70\% of the IFN- $\alpha$-up-regulated genes in MT- 2 were identical of those up-regulated in MT-4 cells, indicating the similarity and reliability of both cell lines as HTLV-1 in vitro models.

Because of the intact transcriptional activation of ISGs, the absence of distinct antiviral activity of IFN- $\alpha$ against HTLV-1 was not due to a general defect in IFN- $\alpha$ signaling pathways in MT-2 or MT-4 cells. In agreement with our findings, over-expression of a subset of ISGs in chronic HTLV-1 infection has recently been shown to fail to constitute an efficient antiviral host response, but might instead contribute to HAM/TSP pathogenesis [55]. We speculate that IFN- $\alpha$ fails to decrease HTLV-1 mRNA levels due to highly virus-specific retroviral restriction factors, as IFN- $\alpha$ exerted strong anti-HIV-1 yet weak anti-HTLV-1 effects in HIV-1/HTLV-1 co-infected MT-4 cells. Since all known HTLV-1 mRNAs, including antisense HBZ, remain unchanged upon IFN treatment, defective RNAseL activity, downstream of OAS gene activation (reviewed in [57]), might be hypothesized as a possible HTLV-1 escape mechanism,. Although several OAS family members are IFN-inducible in both HTLV-1 infection (this study, Table I and results not shown) and HIV-1 infection [40], little is known of downstream RNAse $\mathrm{L}$ activation, which occurs at the protein level [57]. In addition, blunting of IFN- $\alpha$ biological activity has been mainly addressed in HTLV-1 mono-infection, but not in HIV-1/HTLV-1 coinfection. HTLV-1 expression has been reported to up-regulate SOCS1 expression, inducing ubiquitination and proteasomal degradation of IRF3, leading to the inhibition of type I interferon production and thus inhibiting activation of IFN- $\alpha$ signaling pathways [50]. Still, up-regulation of SOCS1 mRNA levels was shown in CD4+ T cells isolated from HAM/TSP patients and asymptomatic carriers, but not from ATLL patients [50]. Furthermore, HTLV-1 Tax has been shown to induce SOCS1 expression, leading to the inhibition of RIG-I-dependent antiviral signaling, but not the JAK/STAT signaling pathways [58]. Inhibition of cytoplasmatic pattern recognition receptors such as RIG-I, has been associated with IRF3 inhibition and thus subsequent inhibition of type I interferon production. Consequently, HTLV-1-induced SOCS1 expression could counteract activation of IFN- $\alpha$ signaling via reduced type I interferon production. However, 

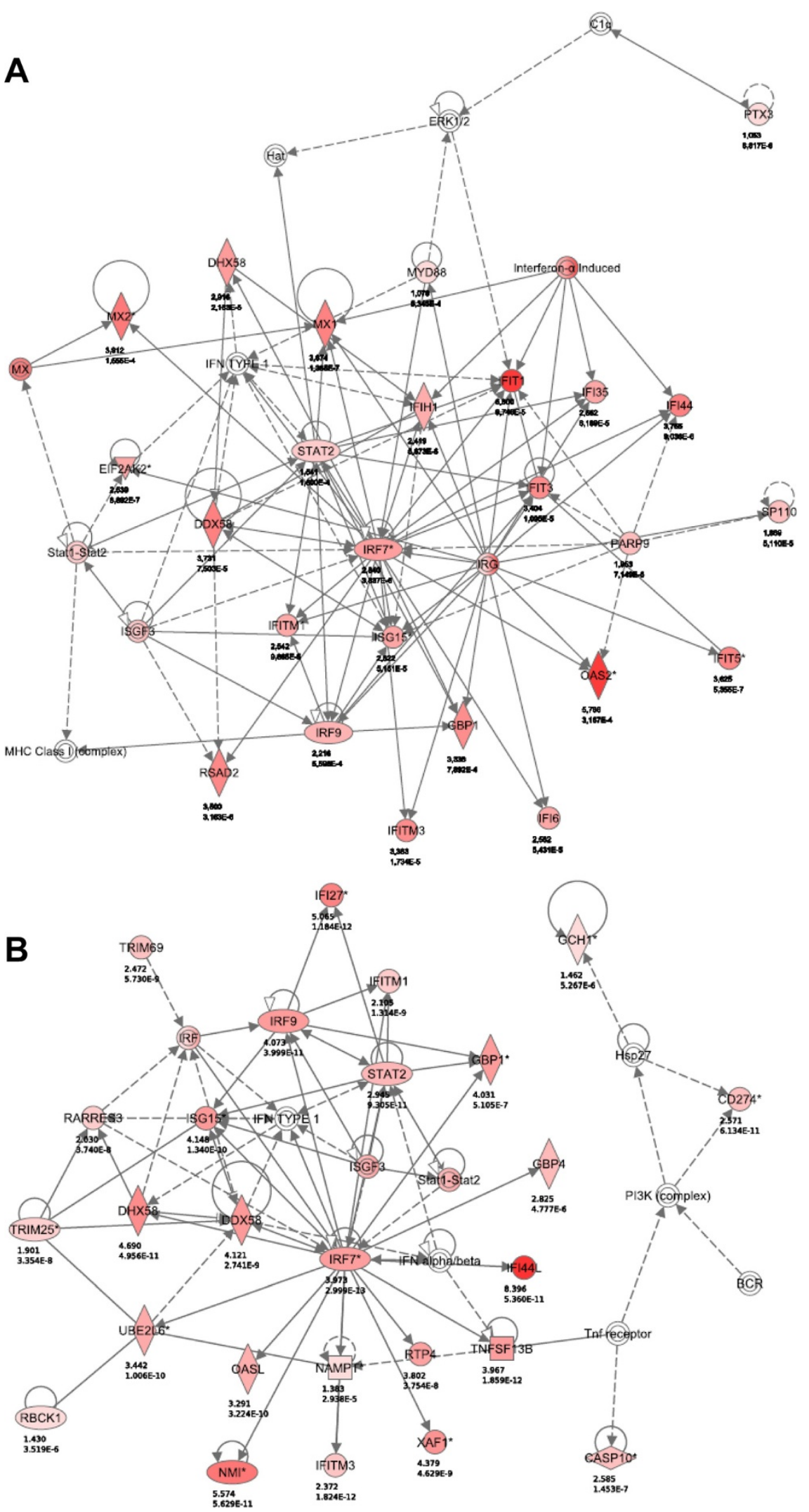

Figure 5 (See legend on next page.) 
(See figure on previous page.)

Figure 5 STAT1/STAT2 signaling pathways predominate following IFN-a treatment in MT-2 and MT-4 cells. Ingenuity Pathway Analysis (IPA) was performed on genes regulated by IFN-a treatment (6 h) in MT-2 (A) and MT-4 cells (B). The red colour indicates up-regulation with the intensity indicating the degree of the gene transcription change. The $\log _{2}$ fold-change values and p-values are indicated below each molecule. Full lines represent direct interactions, while dashed lines indirect interactions. Network shapes are as in Figure 3.

whereas exogenous IFN- $\alpha$ has been shown to increase SOCS1 expression in HeLa-cells, HTLV-1 expressed from an infectious molecular clone reduced IFN- $\alpha-$ induced up-regulation of SOCS1 mRNA levels [48]. Taken together, the precise correlation between HTLV1 and SOCS1 expression and its effect on IFN- $\alpha$ signaling, remains unclear. Our microarray analysis revealed significant IFN- $\alpha$-induced up-regulation of suppressors of cytokine signaling SOCS1, SOCS2 and SOCS3 levels in MT-4 cells, but not in MT-2 cells, although IPA pathway analysis revealed strikingly similar IFN signaling in both cell lines. Therefore, an IFN- $\alpha$-induced increased SOCS1 level is not a generalized finding in HTLV-1 infection in vitro and is not by itself sufficient to define the blunted biological activity of IFN- $\alpha$. HTLV-1 expression has also been reported to upregulate IRF4 levels in HTLV-1-transformed cell lines and PBMCs of ATLL patients [59,60]. IRF4 was shown to negatively regulate type I interferon production and appeared to be associated with AZT + IFN- $\alpha$ antiviral resistance in ATLL patients [59-61]. Our microarray results showed no effect of IFN- $\alpha$ on IRF4 expression in MT-2 or MT-4 cells, although more sensitive nCounter analysis revealed slight IFN- $\alpha$-induced upregulation of IFR4 levels, which was significant in MT4 cells, but not in MT- 2 cells $(p=0.049$ and $p=0.65$, respectively, data not shown). Furthermore, treatment with exogenous IFN- $\alpha$ was able to activate IFN- $\alpha$ signalling to a similar extent in both cell lines (Figure 6A-B and Tables 1-2), although SOCS1 and IRF4 were significantly up-regulated in MT-4 cells only. Nevertheless, our study was limited to the broad antiviral, pro-apoptotic and antiproliferative activities of IFN- $\alpha$, as well as IFN- $\alpha$ signaling in HTLV-1-infected cells, whereas the precise contribution of cellular factors such as SOCS1 or IRF4 has been investigated in detail in previous studies [50,58-61]. However, it should be stated that some of these studies $[48,50]$ investigate de novo infection with HTLV-1 molecular clones, in contrast to stable HTLV-1 infection (this study). The latter might be closer to the in vivo situation, considering the latency of the virus in vivo and its slow molecular evolution, pointing at limited de novo infection [1]. In addition, there is increasing evidence that activation of multiple IFN- $\alpha$ signaling pathways is required to generate the antiviral, pro-apoptotic and immunomodulatory effects of IFN- $\alpha$ [16]. Antiviral and antiproliferative activities of IFN- $\alpha$ have been reported to depend on both STAT- and p38signaling pathways [62]. Although we observed transcriptional activation of STAT1, STAT2 and downstream ISGs in both MT-2 and MT-4 cells, other important IFN- $\alpha$ signaling pathways, such as p38-signaling, could be affected by HTLV-1 replication, possibly explaining the absence of explicit antiviral or antiproliferative activity against HTLV-1 in vitro.

Altogether, one can assume that the in vitro antiretroviral activity and, possibly, the in vivo therapeutic success of IFN- $\alpha$ for both HIV-1 and HTLV-1 is determined by virus-specific factors including viral life cycle-related factors (replication, virion production) and the balance between factors blunting or stimulating IFN- $\alpha$ signaling pathways. For example, inhibition of HIV-1 assembly and release of virions by IFN- $\alpha$ has been described through the induction of ISG15, an ubiquitin-like protein [34]. Through ISG15 up-regulation, IFN- $\alpha$ could affect HTLV-1 assembly, which could explain the posttranscriptional inhibition of p19 secretion. On the other hand, a recent systematic screen for antiviral activity of 389 ISGs, revealed the ability of ADAR to enhance HIV1 replication [31]. Unfortunately, no data are available on IFN signaling and/or specific ISGs levels in HIV-1/ HTLV-1 co-infection, which is of significant clinical importance since several cohort studies have revealed accelerated clinical progression to AIDS and/or increased mortality in HIV-1/HTLV-1 co-infected versus HIV-1 mono-infected individuals [63-65].

\section{Conclusion}

We found that IFN- $\alpha$ treatment of retrovirus-infected $\mathrm{CD} 4+\mathrm{T}$ cells revealed strong anti-HIV-1 but limited anti-HTLV-1 effects. We demonstrate intact early as well as sustained IFN- $\alpha$ signaling in HTLV-1-infected cells, despite various reports of SOCS1- and HTLV-1 Taxinduced blunting of IFN- $\alpha$ signaling. We speculate that qualitative rather than quantitative differences in IFN- $\alpha$ signaling and downstream ISGs could determine the therapeutic success of IFN- $\alpha$ in vivo, depending on both host genetics and disease context. Therefore, large cohorts with long-term clinical follow-up of ATLL and HAM/TSP patients, as well as HIV-1/HTLV-1 coinfected individuals are required to identify viral and host factors specifically limiting antiretroviral activity of IFN- $\alpha$ against HTLV-1. 

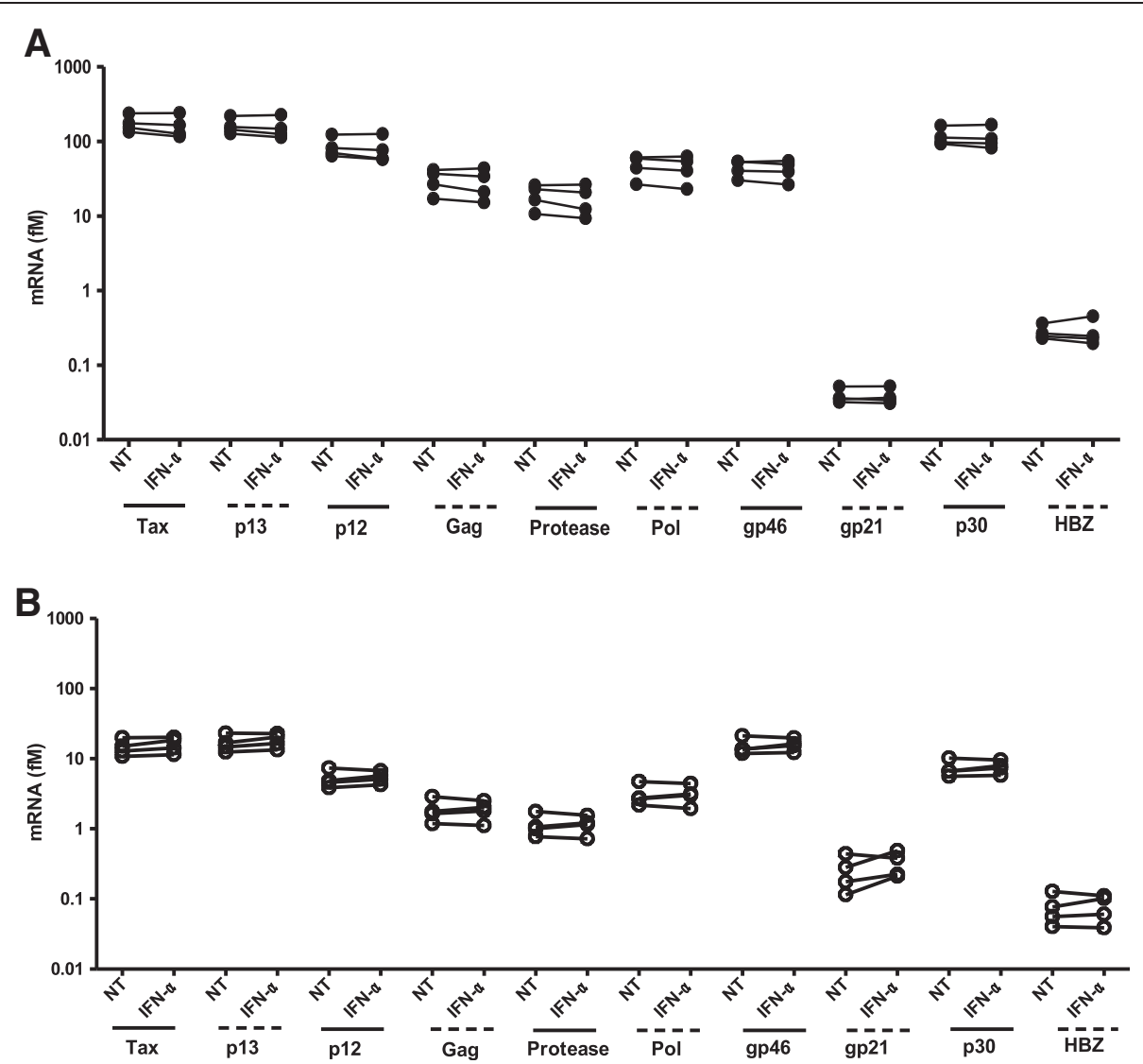

Figure 6 Quantification of HTLV-1 viral mRNA levels after 6 hours of IFN- $\boldsymbol{a}$ treatment. HTLV-1-infected CD4+ T cell lines (A) MT-2 and (B) MT-4 were treated for 6 hours with no treatment (NT) or IFN-a (1000 IU/ml). mRNA levels (fM) of all known HTLV-1 viral genes were assessed via nCounter analysis and shown in the $y$-axis, whereas the treatment conditions are shown in the $x$-axis, represented for each of the viral genes. No statistical significance was observed for any gene (t-test).

\section{Materials and methods Reagents}

IFN- $\alpha 2 \mathrm{~A}\left(3 \times 10^{6} \mathrm{IU} / \mathrm{ml}\right.$, a gift of Blausiegel Farmacêutica, São Paulo, Brazil) stock solutions were prepared in normal saline and working solutions in RPMI 1640 medium, supplemented with $10 \%$ heat inactivated foetal calf serum, $20 \mu \mathrm{g} / \mathrm{ml}$ gentamicin and $75 \mathrm{mM}$ $\mathrm{NaHCO}_{3}\left(\mathrm{GIBCO}^{\circledR}\right.$ Invitrogen, Belgium). Antiviral activity of IFN- $\alpha$ was confirmed in a Vesicular Stomatitis Virus/WISH bioassay [66].

\section{Patients samples and cell lines}

Diagnosis of HTLV-1 infection, HAM/TSP and ATLL was made according to published criteria [67], combining ELISA (Murex), Western blot, INNO-LIA (Innogenetics) and clinical data. Written informed consent was obtained from all participants and this study was approved by the Ethics Committees of CpqGMFIOCRUZ and HUPES/UFBA (Salvador-Bahia, Brazil) and the Universidad Peruana Cayetano Heredia (Lima,
Peru). PBMCs of 5 HAM/TSP and 6 ATLL patients (4 acute, 2 chronic) were isolated by Ficoll-Hypaque density gradient centrifugation (Sigma-Aldrich).

PBMCs and chronically HTLV-1-infected cell lines, C8166, MT-2 and MT-4 [68-70], were cultured in supplemented RPMI 1640 medium. C8166 cells were obtained from the Medical Research Council, UK), MT-2 and MT-4 cells were from Harada et al. [71]. For varying time spans, PBMCs $\left(2 \times 10^{6}\right.$ cells $\left./ \mathrm{ml}\right)$ and HTLV-1-infected cell lines $\left(2 \times 10^{5}\right.$ cells $\left./ \mathrm{ml}\right)$ were treated in the absence or presence of IFN- $\alpha\left(10-10^{4} \mathrm{IU} / \mathrm{ml}\right)$ followed by flow cytometric analysis of HTLV-1-infected cell lines. Given that MT-4 cells are highly susceptible to HIV-1 infection and have been successfully used as a drug screening model for the detection of anti-HIV compounds [53], MT-4 cells $\left(6 \times 10^{5}\right.$ cells $\left./ \mathrm{ml}\right)$ were infected with HIV-1 $\mathrm{III}_{\mathrm{B}}$ strain [72] and cultured for 5 days in the absence or presence of varying concentrations of IFN- $\alpha$ $\left(0.01-10^{4} \mathrm{IU} / \mathrm{ml}\right)$. Hereby, antiviral activity of IFN- $\alpha$ was measured via the 3-(4,5-dimethylthiazol-2-yl)-2,5- 
diphenyltetrazolium bromide (MTT) cell viability staining assay [53,73]. In parallel, HTLV-1-mono-infected MT- 4 cells $\left(6 \times 10^{5}\right.$ cells $\left./ \mathrm{ml}\right)$ were cultured for 5 days in the absence or presence of varying concentrations of IFN- $\alpha$ $\left(10-10^{4} \mathrm{IU} / \mathrm{ml}\right)$. Cell viability was quantified by both MTT assay and trypan blue dye exclusion protocols.

\section{Flow cytometry assay}

At different time points after IFN- $\alpha$ treatment, cell lines were collected and DNA content (Hoechst 33342), cell death-associated (active-caspase-3, surface Fas) and cell proliferation-associated (PCNA) markers were quantified by flow cytometry (BD Biosciences). Briefly, cells were fixed in Cytofix buffer (BD Biosciences) for 10 minutes at $37^{\circ} \mathrm{C}$. Cell pellets were permeabilized in $100 \%$ ice-cold methanol for 30 minutes. Cells were then washed twice in $1 \mathrm{x}$ PBA (phosphatebuffered saline + bovine serum albumin $+\mathrm{NaN}_{3}$ ) and incubated with fluorescence-labelled monoclonal antibodies at room temperature (APC mouse IgG1, FITC mouse IgG2a, PE mouse IgG2a, APC anti-Fas, FITC anti-PCNA, PE anti-active Caspase-3). After 30 minutes, cells were washed twice in $1 \times \mathrm{PBA}$ and stained with Hoechst 33342. Cell populations and debris were defined based on morphology via forward- versus side-scatter plots and 10.000-100.000 events were acquired per sample.

\section{HIV-1 p24 and HTLV-1 p19 quantification}

HIV-1 capsid protein 24 and HTLV-1 matrix protein p19 were quantified in cell-free supernatant of MT-4 and MT-2 cells, using HIV-1 p24 Core Profile ELISA kit (PerkinElmer) and RetroTek HTLV-I/II p19 Antigen ELISA kit (ZeptoMetrix), respectively. After 48-72 hours of IFN- $\alpha$ treatment $(1000 \mathrm{IU} / \mathrm{ml})$, HTLV-1 p19 levels were quantified in cell-free supernatant of HAM/TSP and ATLL PBMCs.

\section{Microarray analysis}

Total RNA was extracted from MT-2 and MT-4 cells treated in the absence or presence of IFN- $\alpha$ (1000 IU/ $\mathrm{ml}$ ) at 6 hours, using RNeasy kit according to the manufacturer's protocol (QIAgen Benelux B.V., Venlo, the Netherlands). Agilent Whole Human Genome microarray analysis was performed by the VIB MicroArray Facility (Leuven, Belgium). Data were analysed using the Agilent Feature Extraction Software version 10.1.1.1 and 10.5.1.1. Briefly, the intensities of the fluorescent probes $\mathrm{Cy} 3$ and $\mathrm{Cy} 5$, representing the transcription values, were $\log _{2}$-transformed and normalized by quantile normalization using the $\mathrm{R}$ package preprocessCore [74]. The contrasts in expression between IFN- $\alpha$-treated and untreated cells at 6 hours of stimulation were estimated using the Limma package from Bioconductor (www. bioconductor.org). For the selection of differentially transcribed genes, a fold-change cut-off of two (i.e. an absolute $\log _{2}$-ratio larger than 1 ) was combined with a p-value cut-off of $\mathrm{p}<0.05$ when corrected for multiple testing. GEO submission of microarray data is detailed in Additional file 2.

\section{Ingenuity pathway analysis}

The Ingenuity Pathway Analysis (IPA) program was used to perform a pathway/function level analysis on genes resulting from the microarray analysis for both MT-2 and MT-4 (IPA version 9.0, Build 116623, Content version 3211, Ingenuity Systems, Red Wood City, CA). Hereby, uncorrected p-values and absolute fold-changes were used with cut-offs of $\mathrm{p}<0.001$ and fold-change value of 2 (up or down), respectively. Based on a scientific literature database, genes were sorted into gene networks and canonical pathways and significantly overrepresented pathways were identified. The maximum number of networks to be generated was set to 25 , with a maximum number of 35 molecules per network. The signaling pathways and networks in Figure 3 were generated through the use of IPA (Ingenuity Systems, www.ingenuity.com).

\section{nCounter analysis}

Total RNA was extracted from MT-2 and MT-4 treated in the absence and presence of IFN- $\alpha(1000 \mathrm{IU} / \mathrm{ml})$ at 2 , 6 and 48 hours, using RNeasy kit according to the manufacturer's protocol (QIAgen Benelux B.V., Venlo, the Netherlands). nCounter ${ }^{\mathrm{TM}}$ (NanoString Technologies, Seattle, United States) analysis was performed at the VIB MicroArray Facility (Leuven, Belgium), based on direct molecular bar-coding of target RNA transcripts and digital detection [56]. Through the use of colour-coded probe pairs, without the use of reverse transcriptase nor amplification, mRNA transcripts of HTLV-1 viral genes and specific cellular genes, including housekeeping genes for normalization, were quantified in MT-2 and MT-4 cells after 2, 6 and 48 hours of IFN- $\alpha$ treatment (HTLV-1 Tax/Rex, Gag, protease, polymerase, gp46, gp21, NC_001436.1; HTLV-1 p13, p12, p30, AB513134; HTLV-1 HBZ, DQ273132; STAT1, NM_007315.2; STAT2, NM_005419.2; STAT3, NM_139276.2; CD69, NM_001781.1).

\section{Statistical analysis}

Statistical analysis was performed with GraphPad Prism 5 software. Parametric $\mathrm{t}$-tests were used and $\mathrm{p}<0.05$ was considered significant.

In microarray analysis, a moderated $t$-test was used, as implemented in the Limma package, to test whether a contrast was significantly different from zero. To verify the false discovery rate, $\mathrm{p}$-values were corrected for multiple testing with Benjamini-Hochberg. 


\section{Additional files}

Additional file 1: Early and late effects of IFN- $a$ on mRNA levels of STAT and HTLV-1 genes. The HTLV-1-infected CD4+ T cell line MT-4 was treated for 2 and 48 hours with no treatment (NT) or IFN-a $(1000 \mathrm{lU} / \mathrm{ml})$. mRNA levels of cellular and viral genes were assessed via nCounter analysis. (A) STAT1 and STAT2 mRNA levels are represented for MT-4 cells after 2 hours of treatment. mRNA levels of (B) HTLV-1 viral genes and (C) STAT1 and STAT2 cellular genes are represented after 48 hours of treatment. mRNA levels (fM) are shown in the $y$-axis, whereas the treatment conditions are shown in the $x$-axis. Parametric t-tests were used with p-values indicated by asterisks $\left(^{*}<0.05,^{* *}<0.01\right.$ and $\left.{ }^{* * *}<0.001\right)$.

\section{Additional file 2: GEO submission microarray data.doc.}

\section{Competing interests}

The author(s) declare that they have no competing interests.

\section{Authors' contributions}

JW conceived this project and designed the experiments. BM carried out the experiments with cell lines and wrote the manuscript. GL, RK and JWW performed the experiments with patient samples. CP and AV participated in the study design and helped to draft the manuscript. MT, EG, AB, LF and $B G C$ provided the patient samples. All authors read and approved the final manuscript.

\section{Acknowledgments}

The authors would like to acknowledge the excellent technical assistance provided by Kimberly Dée, Cindy Heens, Kristien Erven and Kris Uyttersprot. Britta Moens is supported by a Ph.D. grant of the Institute for the Promotion of Innovation through Science and Technology in Flanders (IWT Vlaanderen). This research was supported by FWO G.0778.10, CNPq, VLIR-UOS and "Leerstoel voor Wetenschappelijk onderzoek over infectieziekten in ontwikkelingslanden".

\section{Author details}

${ }^{1}$ Laboratory of Clinical and Epidemiological Virology, Rega Institute for Medical Research, K.U.Leuven, Leuven, Belgium. ' ${ }^{2}$ aboratory for Virology and Chemotherapy, Rega Institute for Medical Research, K.U.Leuven, Leuven, Belgium. ${ }^{3}$ Instituto de Medicina Tropical Alexander von Humboldt, Universidad Peruana Cayetano Heredia, Lima 31, Peru. ${ }^{4}$ Departamento de Medicina, Facultad de Medicina, Universidad Peruana Cayetano Heredia, Lima, Peru. ${ }^{5}$ Gonçalo Moniz Research Center, Oswaldo Cruz Foundation (FIOCRUZ), Salvador-Bahia, Brazil. 'Department of Pathology, Professor Edgar Santos Teaching Hospital, Federal University of Bahia, Salvador-Bahia, Brazil. ${ }^{7}$ Bahia School of Medicine and Public Health, Salvador-Bahia, Brazil. ${ }^{8}$ Centro de Malária e outras Doenças Tropicais, Instituto de Higiene e Medicina Tropical, Universidade Nova de Lisboa, Lisboa, Portugal. ${ }^{9}$ Institute for Immunological Investigation iii-INCT, Sao Paulo, Brazil.

Received: 1 March 2012 Accepted: 17 August 2012 Published: 23 August 2012

\section{References}

1. Verdonck K, Gonzalez E, Van Dooren S, Vandamme AM, Vanham G, Gotuzzo E: Human T-lymphotropic virus 1: recent knowledge about an ancient infection. Lancet Infect Dis 2007, 7(4):266-281.

2. Kallings LO: The first postmodern pandemic: 25 years of HIV/AIDS. J Intern Med 2008, 263(3):218-243.

3. De Clercq E: Antiretroviral drugs. Curr Opin Pharmacol 2010, 10(5):507-515.

4. Gessain A, Barin F, Vernant JC, Gout O, Maurs L, Calender A, de The G: Antibodies to human T-lymphotropic virus type-I in patients with tropical spastic paraparesis. Lancet 1985, 2(8452):407-410.

5. Tajima K, Cartier L: Epidemiological features of HTLV-I and adult T cell leukemia. Intervirology 1995, 38(3-4):238-246.

6. Tsukasaki K, Hermine O, Bazarbachi A, Ratner L, Ramos JC, Harrington W Jr: O'Mahony D, Janik JE, Bittencourt AL, Taylor GP, Yamaguchi K, Utsunomiya A, Tobinai K, Watanabe T: Definition, prognostic factors, treatment, and response criteria of adult T-cell leukemia-lymphoma: a proposal from an international consensus meeting. J Clin Oncol 2009, 27(3):453-459.
7. Bazarbachi A, Plumelle Y, Carlos Ramos J, Tortevoye P, Otrock Z, Taylor G, Gessain A, Harrington W, Panelatti G, Hermine O: Meta-analysis on the use of zidovudine and interferon-alfa in adult T-cell leukemia/lymphoma showing improved survival in the leukemic subtypes. J Clin Oncol 2010, 28(27):4177-4183.

8. Osame M, Usuku K, Izumo S, ljichi N, Amitani H, Igata A, Matsumoto M, Tara M: HTLV-I associated myelopathy, a new clinical entity. Lancet 1986, 1 (8488):1031-1032.

9. Izumo S, Umehara F, Osame M: HTLV-I-associated myelopathy. Neuropathology 2000, 20(Suppl):S65-S68.

10. Nakagawa M, Nakahara K, Maruyama Y, Kawabata M, Higuchi I, Kubota H, Izumo S, Arimura K, Osame M: Therapeutic trials in 200 patients with HTLV-I-associated myelopathy/tropical spastic paraparesis. J Neurovirol 1996, 2(5):345-355.

11. Vallinoto AC, Santana BB, dos Santos EL, Santo RR, Hermes RB, Sousa RC, Cayres-Vallinoto I, Machado LF, Ishak MO, Ishak R: FAS-670A/G single nucleotide polymorphism may be associated with human $T$ lymphotropic virus-1 infection and clinical evolution to TSP/HAM. Virus Res 2012, 163(1):178-182.

12. Farre $L$, Bittencourt $A L$, Silva-Santos $G$, Almeida A, Silva AC, Decanine $D$, Soares GM, Alcantara LC Jr, Van Dooren S, Galvão-Castro B, Vandamme AM, Van Weyenbergh J: Fas 670 promoter polymorphism is associated to susceptibility, clinical presentation, and survival in adult T cell leukemia. J Leukoc Biol 2008, 83(1):220-222.

13. Lane HC, Davey V, Kovacs JA, Feinberg J, Metcalf JA, Herpin B, Walker R, Deyton L, Davey RT Jr, Falloon J, et al: Interferon-alpha in patients with asymptomatic human immunodeficiency virus (HIV) infection. A randomized, placebo-controlled trial. Ann Intern Med 1990, 112(11): 805-811.

14. Isaacs A, Lindenmann J: Virus interference. I. The interferon. Proc $R$ Soc Lond B Biol Sci 1957, 147(927):258-267.

15. Takaoka A, Yanai $\mathrm{H}$ : Interferon signalling network in innate defence. Cell Microbiol 2006, 8(6):907-922.

16. Platanias LC: Mechanisms of type-I- and type-II-interferon-mediated signalling. Nat Rev Immunol 2005, 5(5):375-386.

17. Taniguchi T, Takaoka A: The interferon-alpha/beta system in antiviral responses: a multimodal machinery of gene regulation by the IRF family of transcription factors. Curr Opin Immunol 2002, 14(1):111-116.

18. Trinchieri G: Type I interferon: friend or foe? J Exp Med 2010, 207(10):2053-2063.

19. de Veer MJ, Holko M, Frevel M, Walker E, Der S, Paranjape JM, Silverman RH, Williams BR: Functional classification of interferon-stimulated genes identified using microarrays. J Leukoc Biol 2001, 69(6):912-920.

20. Goujon C, Malim MH: Characterization of the alpha interferon-induced postentry block to HIV-1 infection in primary human macrophages and T cells. J Virol 2010, 84(18):9254-9266.

21. Borden EC, Sen GC, Uze G, Silverman RH, Ransohoff RM, Foster GR, Stark GR: Interferons at age 50: past, current and future impact on biomedicine. Nat Rev Drug Discov 2007, 6(12):975-990.

22. King JK, Yeh SH, Lin MW, Liu CJ, Lai MY, Kao JH, Chen DS, Chen PJ: Genetic polymorphisms in interferon pathway and response to interferon treatment in hepatitis B patients: A pilot study. Hepatology 2002, 36(6):1416-1424

23. Pflugheber J, Fredericksen B, Sumpter R Jr, Wang C, Ware F, Sodora DL, Gale $\mathrm{M}$ Jr: Regulation of PKR and IRF-1 during hepatitis $C$ virus RNA replication. Proc Natl Acad Sci USA 2002, 99(7):4650-4655.

24. Golomb HM: Hairy cell leukemia: treatment successes in the past 25 years. J Clin Oncol 2008, 26(16):2607-2609.

25. Fried MW, Shiffman ML, Reddy KR, Smith C, Marinos G, Goncales FL Jr, Haussinger D, Diago M, Carosi G, Dhumeaux D, Craxi A, Lin A, Hoffman J, Yu J: Peginterferon alfa-2a plus ribavirin for chronic hepatitis $C$ virus infection. N Engl J Med 2002, 347(13):975-982.

26. Ferrantini M, Capone I, Belardelli F: Interferon-alpha and cancer: mechanisms of action and new perspectives of clinical use. Biochimie 2007, 89(6-7):884-893.

27. Moschos S, Kirkwood JM: Present role and future potential of type I interferons in adjuvant therapy of high-risk operable melanoma. Cytokine Growth Factor Rev 2007, 18(5-6):451-458.

28. van Boxel-Dezaire AH, Rani MR, Stark GR: Complex modulation of cell type-specific signaling in response to type I interferons. Immunity 2006, 25(3):361-372 
29. Chevaliez S, Pawlotsky JM: Interferon-based therapy of hepatitis C. Adv Drug Deliv Rev 2007, 59(12):1222-1241.

30. Pestka S, Krause CD, Walter MR: Interferons, interferon-like cytokines, and their receptors. Immunol Rev 2004, 202:8-32.

31. Schoggins JW, Wilson SJ, Panis M, Murphy MY, Jones CT, Bieniasz P, Rice $\mathrm{CM}$ : A diverse range of gene products are effectors of the type I interferon antiviral response. Nature 2011, 472(7344):481-485.

32. Korth MJ, Taylor MD, Katze MG: Interferon inhibits the replication of HIV-1, SIV, and SHIV chimeric viruses by distinct mechanisms. Virology 1998, 247(2):265-273.

33. Hartshorn KL, Neumeyer D, Vogt MW, Schooley RT, Hirsch MS: Activity of interferons alpha, beta, and gamma against human immunodeficiency virus replication in vitro. AIDS Res Hum Retroviruses 1987, 3(2): 125-133.

34. Okumura A, Lu G, Pitha-Rowe I, Pitha PM: Innate antiviral response targets HIV-1 release by the induction of ubiquitin-like protein ISG15. Proc Nat Acad Sci USA 2006, 103(5):1440-1445.

35. Agy MB, Acker RL, Sherbert CH, Katze MG: Interferon treatment inhibits virus replication in HIV-1- and SIV-infected CD4+ T-cell lines by distinct mechanisms: evidence for decreased stability and aberrant processing of HIV-1 proteins. Virology 1995, 214(2):379-386

36. Baca-Regen L, Heinzinger N, Stevenson M, Gendelman HE: Alpha interferon-induced antiretroviral activities: restriction of viral nucleic acid synthesis and progeny virion production in human immunodeficiency virus type 1-infected monocytes. J Virol 1994, 68(11):7559-7565.

37. Coccia EM, Krust B, Hovanessian AG: Specific inhibition of viral protein synthesis in HIV-infected cells in response to interferon treatment. J Biol Chem 1994, 269(37):23087-23094.

38. Yamamoto JK, Barre-Sinoussi F, Bolton V, Pedersen NC, Gardner MB: Human alpha- and beta-interferon but not gamma- suppress the in vitro replication of LAV, HTLV-III, and ARV-2. J Interferon Res 1986, 6(2):143-152.

39. Mandl JN, Barry AP, Vanderford TH, Kozyr N, Chavan R, Klucking S, Barrat FJ, Coffman RL, Staprans SI, Feinberg MB: Divergent TLR7 and TLR9 signaling and type I interferon production distinguish pathogenic and nonpathogenic AIDS virus infections. Nat Med 2008, 14(10):1077-1087.

40. Rotger M, Dang KK, Fellay J, Heinzen EL, Feng S, Descombes P, Shianna KV, Ge D, Gunthard HF, Goldstein DB, Telenti A: Genome-wide mRNA expression correlates of viral control in CD4+ T-cells from HIV-1-infected individuals. PLoS Pathog 2010, 6(2):e1000781.

41. von Sydow M, Sonnerborg A, Gaines H, Strannegard O: Interferon-alpha and tumor necrosis factor-alpha in serum of patients in various stages of HIV-1 infection. AIDS Res Hum Retroviruses 1991, 7(4):375-380.

42. Gringeri A, Musicco M, Hermans $P$, Bentwich $Z$, Cusini M, Bergamasco A, Santagostino E, Burny A, Bizzini B, Zagury D: Active anti-interferonalpha immunization: a European-Israeli, randomized, double-blind, placebo-controlled clinical trial in 242 HIV-1-infected patients (the EURIS study). J Acquir Immune Defic Syndr Hum Retrovirol 1999, 20(4):358-370.

43. Herbeuval JP, Shearer GM: HIV-1 immunopathogenesis: how good interferon turns bad. Clin Immunol 2007, 123(2):121-128

44. Haas DW, Lavelle J, Nadler JP, Greenberg SB, Frame P, Mustafa N, St Clair M, McKinnis R, Dix L, Elkins $M$, Rooney J: A randomized trial of interferon alpha therapy for HIV type 1 infection. AIDS Res Hum Retroviruses 2000, 16 (3):183-190.

45. Asmuth DM, Murphy RL, Rosenkranz SL, Lertora JJ, Kottilil S, Cramer Y, Chan ES, Schooley RT, Rinaldo CR, Thielman N, Li XD, Wahl SM, Shore J, Janik J, Lempicki RA, Simpson Y, Pollard RB: Safety, tolerability, and mechanisms of antiretroviral activity of pegylated interferon Alfa-2a in HIV-1monoinfected participants: a phase II clinical trial. J Infect Dis 2010, 201 (11):1686-1696.

46. Hatzakis A, Gargalianos P, Kiosses V, Lazanas M, Sypsa V, Anastassopoulou C, Vigklis V, Sambatakou H, Botsi C, Paraskevis D, Stalgis C: Low-dose IFNalpha monotherapy in treatment-naive individuals with HIV-1 infection: evidence of potent suppression of viral replication. $J$ Interferon Cytokine Res 2001, 21(10):861-869.

47. Feng $X$, Heyden NV, Ratner L: Alpha interferon inhibits human T-cell leukemia virus type 1 assembly by preventing Gag interaction with rafts. J Virol 2003, 77(24):13389-13395.

48. Feng $X$, Ratner L: Human T-cell leukemia virus type 1 blunts signaling by interferon alpha. Virology 2008, 374(1):210-216.
49. Zhang J, Yamada O, Kawagishi K, Araki H, Yamaoka S, Hattori T, Shimotohno K: Human T-cell leukemia virus type 1 Tax modulates interferon-alpha signal transduction through competitive usage of the coactivator CBP/ p300. Virology 2008, 379(2):306-313.

50. Oliere S, Hernandez E, Lezin A, Arguello M, Douville R, Nguyen TL, Olindo S, Panelatti G, Kazanji M, Wilkinson P, Sekaly RP, Cesaire R, Hiscott J: HTLV-1 evades type I interferon antiviral signaling by inducing the suppressor of cytokine signaling 1 (SOCS1). PLoS Pathog 2010, 6(11):e1001177.

51. Gill PS, Harrington W Jr, Kaplan MH, Ribeiro RC, Bennett JM, Liebman HA, Bernstein-Singer M, Espina BM, Cabral L, Allen S, et al: Treatment of adult T-cell leukemia-lymphoma with a combination of interferon alfa and zidovudine. N Engl J Med 1995, 332(26):1744-1748.

52. Izumo S, Goto I, Itoyama Y, Okajima T, Watanabe S, Kuroda Y, Araki S, Mori M, Nagataki S, Matsukura S, Akamine T, Nakagawa M, Yamamoto I, Osame M: Interferon-alpha is effective in HTLV-I-associated myelopathy: a multicenter, randomized, double-blind, controlled trial. Neurology 1996, 46(4):1016-1021.

53. Pannecouque C, Daelemans D, De Clercq E: Tetrazolium-based colorimetric assay for the detection of HIV replication inhibitors: revisited 20 years later. Nat Protoc 2008, 3(3):427-434.

54. Moens B, Decanine D, Menezes SM, Khouri R, Silva-Santos G, Lopez G, Alvarez C, Talledo M, Gotuzzo E, de Almeida Kruschewsky R, Galvão-Castro B, Vandamme AM, Van Weyenbergh J: Ascorbic Acid Has Superior Ex Vivo Antiproliferative, Cell Death-Inducing and Immunomodulatory Effects over IFN-a in HTLV-1-Associated Myelopathy. PLoS Negl Trop Dis 2012, 6(7):e1729.

55. Tattermusch S, Skinner JA, Chaussabel D, Banchereau J, Berry MP, McNab FW, O'Garra A, Taylor GP, Bangham CR: Systems Biology Approaches Reveal a Specific Interferon-Inducible Signature in HTLV-1 Associated Myelopathy. PLOS Pathog 2012, 8(1):e1002480.

56. Geiss GK, Bumgarner RE, Birditt B, Dahl T, Dowidar N, Dunaway DL, Fell HP, Ferree S, George RD, Grogan T, James JJ, Maysuria M, Mitton JD, Oliveri P, Osborn JL, Peng T, Ratcliffe AL, Webster PJ, Davidson EH, Hood L, Dimitrov $K$ : Direct multiplexed measurement of gene expression with color-coded probe pairs. Nat Biotechnol 2008, 26(3):317-325.

57. Chakrabarti A, Jha BK, Silverman RH: New insights into the role of RNase L in innate immunity. J Interferon Cytokine Res 2011, 31(1):49-57.

58. Charoenthongtrakul S, Zhou Q, Shembade N, Harhaj NS, Harhaj EW: Human T cell leukemia virus type 1 Tax inhibits innate antiviral signaling via NF-kappaB-dependent induction of SOCS1. J Virol 2011, 85(14):6955-6962.

59. Sharma S, Grandvaux N, Mamane Y, Genin P, Azimi N, Waldmann T, Hiscott $\mathrm{J}$ : Regulation of IFN regulatory factor 4 expression in human T cell leukemia virus-I-transformed T cells. J Immunol 2002, 169(6):3120-3130

60. Imaizumi Y, Kohno T, Yamada Y, Ikeda S, Tanaka Y, Tomonaga M, Matsuyama T: Possible involvement of interferon regulatory factor 4 (IRF4) in a clinical subtype of adult T-cell leukemia. Jpn J Cancer Res 2001, 92(12):1284-1292.

61. Ramos JC, Ruiz P Jr, Ratner L, Reis IM, Brites C, Pedroso C, Byrne GE Jr, Toomey NL, Andela V, Harhaj EW, Lossos IS, Harrington WJ Jr: IRF-4 and c-Rel expression in antiviral-resistant adult T-cell leukemia/lymphoma. Blood 2007, 109(7):3060-3068.

62. Platanias $L C:$ The $\mathrm{p} 38$ mitogen-activated protein kinase pathway and its role in interferon signaling. Pharmacol Ther 2003, 98(2):129-142.

63. Pedroso C, Netto EM, Weyll N, Brites C: Coinfection by HIV-1 and human lymphotropic virus type 1 in Brazilian children is strongly associated with a shorter survival time. J Acquir Immune Defic Syndr 2011, 57(Suppl 3):S208-S211.

64. Schechter M, Harrison LH, Halsey NA, Trade G, Santino M, Moulton LH, Quinn TC: Coinfection with human T-cell lymphotropic virus type I and HIV in Brazil. Impact on markers of HIV disease progression. JAMA 1994, 271(5):353-357.

65. Brites C, Sampalo J, Oliveira A: HIV/human T-cell lymphotropic virus coinfection revisited: impact on AIDS progression. AIDS Rev 2009, 11(1):8-16.

66. Van Weyenbergh J, Lipinski P, Abadie A, Chabas D, Blank U, Liblau R, Wietzerbin J: Antagonistic action of IFN-beta and IFN-gamma on high affinity Fc gamma receptor expression in healthy controls and multiple sclerosis patients. J Immunol 1998, 161(3):1568-1574.

67. Carneiro-Proietti AB, Catalan-Soares BC, Castro-Costa CM, Murphy EL, Sabino EC, Hisada M, Galvao-Castro B, Alcantara LC, Remondegui C, Verdonck K, Proietti FA: HTLV in the Americas: challenges and perspectives. Rev Panam Salud Publica 2006, 19(1):44-53. 
68. Miyoshi I, Yoshimoto S, Kubonishi I, Taguchi H, Shiraishi Y, Ohtsuki Y, Akagi $\mathrm{T}$ : Transformation of normal human cord lymphocytes by co-cultivation with a lethally irradiated human T-cell line carrying type $C$ virus particles. Gann 1981, 72(6):997-998.

69. Salahuddin SZ, Markham PD, Wong-Staal F, Franchini G, Kalyanaraman VS, Gallo RC: Restricted expression of human T-cell leukemia-lymphoma virus (HTLV) in transformed human umbilical cord blood lymphocytes. Virology 1983, 129(1):51-64.

70. Miyoshi I, Kubonishi I, Yoshimoto S, Shiraishi Y: A T-cell line derived from normal human cord leukocytes by co-culturing with human leukemic T-cells. Gann 1981, 72(6):978-981.

71. Harada S, Koyanagi Y, Yamamoto N: Infection of HTLV-III/LAV in HTLV-Icarrying cells MT-2 and MT-4 and application in a plaque assay. Science 1985, 229(4713):563-566.

72. Popovic M, Sarngadharan MG, Read E, Gallo RC: Detection, isolation, and continuous production of cytopathic retroviruses (HTLV-III) from patients with AIDS and pre-AIDS. Science 1984, 224(4648):497-500.

73. Pauwels R, Balzarini J, Baba M, Snoeck R, Schols D, Herdewijn P, Desmyter J, De Clercq E: Rapid and automated tetrazolium-based colorimetric assay for the detection of anti-HIV compounds. J Virol Methods 1988, 20(4):309-321.

74. Bolstad BM, Irizarry RA, Astrand M, Speed TP: A comparison of normalization methods for high density oligonucleotide array data based on variance and bias. Bioinformatics 2003, 19(2):185-193.

doi:10.1186/1743-422X-9-171

Cite this article as: Moens et al.: Simultaneous RNA quantification of human and retroviral genomes reveals intact interferon signaling in HTLV-1-infected CD4+ T cell lines. Virology Journal 2012 9:171.

\section{Submit your next manuscript to BioMed Central and take full advantage of:}

- Convenient online submission

- Thorough peer review

- No space constraints or color figure charges

- Immediate publication on acceptance

- Inclusion in PubMed, CAS, Scopus and Google Scholar

- Research which is freely available for redistribution

Submit your manuscript at www.biomedcentral.com/submit
() Biomed Central 